\title{
Adverse events following immunization of combined diphtheria, whole-cell pertussis, tetanus, and hepatitis $B(\mathrm{DPwT} / \mathrm{HB})$ vaccine
}

\author{
Diana Mettadewi Jong, MD; Alan R Tumbelaka, MD; Abdul Latief, MD
}

\begin{abstract}
Background Combined vaccine of diphtheria, whole-cell pertussis, tetanus, and hepatitis B (DPwT/HB) will reduce the number of injections to children and simplify the delivery logistics. The adverse events following immunization (AEFI) of this vaccine have to be concerned since the events may increase or decrease.

Objectives To evaluate AEFI of DPwT/HB vaccine in healthy infants.

Methods A descriptive prospective study of AEFI of three doses of DPwT/HB vaccine was performed on 74 healthy infants aged two to six months at the Department of Child Health, Cipto Mangunkusumo Hospital, from July 2000 to March 2001.

Results Out of 74 infants, 68 received two doses and 67 completed the study with a total of 209 doses. Of 209 doses, adverse events were reported following 126 doses (60.3\%), consisted of systemic $(60.3 \%)$ and local reactions (9.5\%). The three most frequent AEFI iwere mild fever $(44.5 \%)$, high fever $(15.7 \%)$, irritability $(31.5 \%)$. Most AEFI were coincidental $(51.1 \%)$, occurred after more than 72 hours (31.4\%) and lasted less than 24 hours (17.7\%). Systemic reactions were mostly found in 4-month-old infants (33.3\%), while local reactions in 2-, 3-, and 5-month-old infants (25\%), respectively.

Conclusion Most AEFI were coincidental and resolved without any complication [Paediatr Indones 2004;44:209-214].
\end{abstract}

Keywords: adverse events, combined vaccines, $\mathrm{DP} w \mathrm{~T} / \mathrm{HB}$ vaccine.

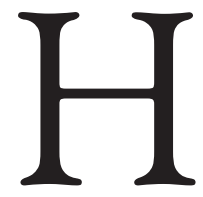
epatitis B infection continues to be a worldwide health concern. The World Health Organization (WHO) estimated that currently, there are over 350 million chronic carriers of the hepatitis B virus worldwide. According to $\mathrm{WHO}$, significant global reduction of hepatitis B infection can only be achieved through universal vaccination. ${ }^{1,2}$ Nowadays, diphtheria, pertussis, and tetanus still warrant attention since these diseases infect millions of people with serious complications. Diphtheria, pertussis, and tetanus vaccine (DPT) has been developed since 1943, and together with the hepatitis B vaccine $(\mathrm{HB})$, has been included in the WHO expanded program on immunization (EPI). Combining HB with DPT is viable since both vaccines are adsorbed and given in multiple doses. Various strategies are being investigated to produce a combined $\mathrm{DPT} / \mathrm{HB}$ vaccine.

A combined vaccine would reduce the number of injections to children and simplify the delivery logistics. Besides these advantages, AEFI of these combined vaccines should be taken into consideration since the events may vary. ${ }^{3-10}$ The objective of this study was to evaluate the adverse events following three doses of a combined diphtheria, whole-cell pertussis, tetanus, and hepatitis $\mathrm{B}(\mathrm{DPwT} / \mathrm{HB})$ vaccine administered to healthy two- to six-month-old infants.

From the Department of Child Health, Medical School University of Indonesia, Cipto Mangunkusumo Hospital, Jakarta, Indonesia.

Reprint requests to: Diana Mettadewi Jong, MD, Department of Child Health, Medical School, University of Indonesia, Cipto Mangunkusumo Hospital, Jakarta, Indonesia. Tel. 62-21-3907742, Fax. 62-21-3907743, email: mj_diana@idai.or.id 
Methods

The study was performed from July 2000 to March 2001 on 74 healthy two-to six-month-old infants recruited from the Growth and Development Clinic at the Department of Child Health, Cipto Mangunkusumo Hospital. The inclusion criteria were no evidence of disease or fever, no history of allergy to any components of DPT or $\mathrm{HB}$, and no history of high fever, shock, unusual or persistent crying, or convulsion occurring within 48 hours after former immunization. Prior to the study, informed consent was obtained from the parents.

The combined $\mathrm{DPwT} / \mathrm{HB}$ vaccine used in this study was Tritanrix $\mathrm{HB}^{(\mathrm{R})}$, manufactured by Smith Kline Beecham. One dose $(0.5 \mathrm{ml})$ of this vaccine contained $\geq 30$ IU of diphtheria toxoid, $\geq 60$ IU of tetanus toxoid, $\geq 4$ IU of inactivated whole-cell $B$ pertussis bacteria, and $10 \mathrm{mg}$ of recombinant hepatitis B surface antigen, adsorbed onto $0.6 \mathrm{mg}$ of aluminum salts and preserved with $25 \mathrm{mg}$ of thimerosal and 50 mg of phenoxyethanol.

Three doses of vaccine were injected intramuscularly in the anterolateral thigh in 5-week interval. For the first 15 minutes after each vaccination, the infants were observed by a physician for any adverse event. Parents were then asked to observe their infants for 5 weeks following each vaccination for any adverse event. Parents were given diary cards to record the observations and were asked to return these cards on the following visit. These cards were designed for recording information on local and systemic reactions, time of onset, and duration of reactions. A thermometer was given to each infant enrolled. Any of the following reactions constituted a contraindication to the vaccine and excluded the infants for subsequent doses i.e., body temperature of $\geq 40.4^{\circ} \mathrm{C}$, persistent screaming or crying for 3 hours within 48 hours following vaccination, convulsions, encephalopathy, hypotonichyporesponsive episode, Guillain-Barre syndrome, and shock following vaccination.

Parents were asked to bring their infants to the clinic or emergency room if any reaction occurred. All of the AEFI were reported to AEFI committee Ministry of Health for AEFI classification audit based on The WHO Western Pacific (1999) classification of AEFI. ${ }^{11,12}$ The audit was performed on 5th-6th July 2003.

\section{Results}

A total of 74 infants were enrolled, 68 infants received two doses of the vaccine, and 67 infants completed the study, so that the total dose administered were 209. Of the 7 infants who were withdrawn from the study, 2 was due to convulsion following immunization of the first and third doses of the vaccine. Table 1 shows the characteristics of infants enrolled in this study. Five weeks of age were added to all infants in the following doses.

Table 1. Characteristics of the INFANTS ENROLled IN THIS STUDY.

\begin{tabular}{lccc}
\hline & $\begin{array}{c}\text { First dose } \\
\mathbf{n}(\%)\end{array}$ & $\begin{array}{c}\text { Second dose } \\
\mathbf{n}(\%)\end{array}$ & $\begin{array}{c}\text { Third dose } \\
\mathbf{n}(\%)\end{array}$ \\
\hline Sex & & & \\
$\quad$ Male & $39(53)$ & $35(52)$ & $35(52)$ \\
$\quad$ Female & $35(47)$ & $33(48)$ & $32(48)$ \\
$\quad$ Total & $74(100)$ & $68(100)$ & $67(100)$ \\
& & & \\
Age (months) & & & \\
2 & $41(55)$ & $0(0.0)$ & $0(0)$ \\
3 & $22(30)$ & $39(57)$ & $0(0)$ \\
4 & $7(10)$ & $20(29)$ & $38(57)$ \\
5 & $4(5)$ & $6(9)$ & $20(30)$ \\
6 & $0(0)$ & $3(4)$ & $6(9)$ \\
7 & $0(0)$ & $0(0.0)$ & $3(4)$ \\
8 & $0(0)$ & $0(0.0)$ & $0(0.0)$ \\
Total & $74(100)$ & $68(100)$ & $67(100)$ \\
\hline Note: ${ }^{*}$ ages of infants were assessed in months, according to month in the \\
category.
\end{tabular}

Of a total of 209 doses, adverse events were reported following 126 doses $(60.3 \%)$ consisting of 126 systemic $(60.3 \%)$ and 20 local reactions (9.5\%). There were 262 adverse events reported. More than one events may be found in one dose. Two cases of general convulsion were reported in three-month-old and four-month-old male infants. The seizures were accompanied by high fever $\left(40.5^{\circ} \mathrm{C}\right.$ and $39.8^{\circ} \mathrm{C}$, respectively), occurred in 11.5 and 16 hours following the first and third doses of the vaccine, each resolved within 1-5 minutes. No sequelae was reported and no hospitalization was needed for these reactions. Difference in proportions with increased number of doses given was not statistically significant for systemic $(p=0.750)$ and local reactions $(p=0.149)$. Table 2 shows adverse events following each dose of this combined vaccine. 
Diana M Jong et al: Adverse events of diphtheria, pertussis, tetanus, and hepatitis B vaccination

Table 2. Adverse eVents following each dose of COMBINED DPWT/HB VACCINE.

\begin{tabular}{|c|c|c|c|c|}
\hline & $\begin{array}{c}1^{\text {st }} \text { dose } \\
\mathrm{N}=74 \\
\mathrm{n}(\%)\end{array}$ & $\begin{array}{c}2^{\text {nd }} \text { dose } \\
\mathrm{N}=68 \\
\mathrm{n}(\%)\end{array}$ & $\begin{array}{c}3^{\text {rd }} \text { dose } \\
\mathrm{N}=67 \\
\mathrm{n}(\%)\end{array}$ & $\begin{array}{c}\text { TOTAL } \\
\mathrm{N}=209 \\
\text { n (\%) }\end{array}$ \\
\hline \multicolumn{5}{|c|}{ Systemic reactions } \\
\hline Mild fever* & $34(46)$ & $27(40)$ & $32(48)$ & $93(45)$ \\
\hline High fever ${ }^{\dagger}$ & $14(19)$ & $10(15)$ & $9(13)$ & $33(16)$ \\
\hline Irritability & $25(34)$ & $25(37)$ & $16(24)$ & $66(32)$ \\
\hline Vomiting & $9(12)$ & $7(10)$ & $4(6)$ & $20(10)$ \\
\hline Malaise & $5(7)$ & $4(6)$ & $3(5)$ & $12(6)$ \\
\hline Diarrhea & $5(7)$ & $3(4)$ & $1(2)$ & $9(4)$ \\
\hline Wheals & $4(5)$ & $1(2)$ & $1(2)$ & $6(3)$ \\
\hline Convulsion & $1(1)$ & $0(0)$ & $1(2)$ & $2(1)$ \\
\hline Pale & $1(1)$ & $0(0)$ & $0(0)$ & $1(1)$ \\
\hline \multicolumn{5}{|c|}{ Local reactions } \\
\hline Pain & $1(1)$ & $0(0)$ & $0(0)$ & $1(1)$ \\
\hline Swelling & $10(14)$ & $4(6)$ & $5(8)$ & $19(9)$ \\
\hline \multicolumn{5}{|c|}{ Note: $\mathrm{N}=$ total number of vaccine given in each dose. } \\
\hline \multicolumn{5}{|c|}{$\begin{array}{l}\mathrm{n}=\text { number of particular adverse events reported following each dose. } \\
\%=\text { percentages of doses administered that were accompanied by a } \\
\text { particular adverse events. } \\
*=\text { the body temperature } 37.5-38.5^{\circ} \mathrm{C} . \\
\dagger=\text { the body temperature }>38.5^{\circ} \mathrm{C} \text {. } \\
==\text { one to three mosquito bite-like wheals localized on the cheeks }\end{array}$} \\
\hline
\end{tabular}

A total of 262 adverse events were reported to AEFI Committee Ministry of Health for a classification audit. Table 3 shows the classification of AEFI of DPwT/HB in this study according to the audit results.

Most AEFI occurred in 4-5 hours following immunization $(22.1 \%)$ and lasted for $2-3$ hours (21.4\%). Mild fever was mostly reported in 4-5 hours following immunization (21\%) and resolved within 2-3 hours (25\%). Most high fever in this study oc- curred in more than 72 hours ( 8 out of 33 cases) and resolved within 2-3 hours (7 of 33 cases). Irritability was mostly reported in 2-3 hours following immunization (24\%) and resolved within 2-3 hours $(23 \%)$. Two cases of febrile convulsion occurred in 11.5 and 16 hours following immunization, respectively and each ceased in 1-5 minutes. Most vomiting, diarrhea, malaise, and wheals occurred in more than 72 hours following immunization, and lasted less than 24 hours. A case of local pain was reported in 2-3 hours following immunization and resolved spontaneously within 24 hours. Local swelling was frequently reported in 2-3 hours (7 out of 19 cases) and disappeared spontaneously in 14-15 hours. Pale was reported in one dose, occurred in 20 minutes following immunization and resolved within 15 minutes. There was one event of local pain which occurred in 2-3 hours and lasted for 24 hours.

Most AEFI was reported in 4-month-old infants (36.5\%). The adverse events spread almost evenly between sexes. Table 4 shows systemic and local reactions following DPwT/HB based on age and sex.

\section{Discussion}

Of 209 doses, 126 (60.3\%) were followed by adverse events. These results were less than those reported in similar previous studies in Spain $(100 \%),{ }^{5}$ Lithuania (>90\%), ${ }^{6}$ and Greece $(100 \%) .{ }^{7}$ The

Table 3. Classification of AEFI of DPwT/HB according to the audit by AEFI Committee MinistRY OF HEALTH

\begin{tabular}{|c|c|c|c|c|c|c|c|c|c|c|c|c|}
\hline \multirow[b]{2}{*}{ Adverse events } & \multicolumn{2}{|c|}{ I } & \multicolumn{2}{|c|}{ II } & \multicolumn{2}{|c|}{ III } & \multicolumn{2}{|c|}{ IV } & \multicolumn{2}{|c|}{ V } & \multicolumn{2}{|c|}{ TOTAL } \\
\hline & $\mathbf{n}$ & (\%) & $\mathbf{n}$ & $(\%)$ & $\mathbf{n}$ & $(\%)$ & $\mathbf{n}$ & $(\%)$ & $\mathbf{n}$ & $(\%)$ & $\mathbf{n}$ & $(\%)$ \\
\hline Mild fever & 0 & 0.0 & 0 & 0.0 & 50 & 19.1 & 43 & 16.4 & 0 & 0.0 & 93 & 35.5 \\
\hline High fever & 0 & 0.0 & 0 & 0.0 & 14 & 5.3 & 19 & 7.3 & 0 & 0.0 & 33 & 12.6 \\
\hline Irritability & 0 & 0.0 & 0 & 0.0 & 30 & 11.5 & 36 & 13.7 & 0 & 0.0 & 66 & 25.2 \\
\hline Vomiting & 0 & 0.0 & 0 & 0.0 & 11 & 4.2 & 9 & 3.4 & 0 & 0.0 & 20 & 7.6 \\
\hline Convulsion & 0 & 0.0 & 0 & 0.0 & 2 & 0.8 & 0 & 0.0 & 0 & 0.0 & 2 & 0.8 \\
\hline Malaise & 0 & 0.0 & 0 & 0.0 & 0 & 0.0 & 12 & 4.6 & 0 & 0.0 & 12 & 4.6 \\
\hline Pale & 0 & 0.0 & 1 & 0.5 & 0 & 0.0 & 0 & 0.0 & 0 & 0.0 & 1 & 0.4 \\
\hline Diarrhea & 0 & 0.0 & 0 & 0.0 & 0 & 0.0 & 9 & 3.4 & 0 & 0.0 & 9 & 3.4 \\
\hline Wheals on cheek/arm/leg & 0 & 0.0 & 0 & 0.0 & 0 & 0.0 & 6 & 2.3 & 0 & 0.0 & 6 & 2.3 \\
\hline Local swelling & 0 & 0.0 & 0 & 0.0 & 19 & 7.3 & 0 & 0.0 & 0 & 0.0 & 19 & 7.3 \\
\hline Local pain & 0 & 0.0 & 0 & 0.0 & 1 & 0.4 & 0 & 0.0 & 0 & 0.0 & 1 & 0.4 \\
\hline Total & 0 & 0.0 & 1 & 0.4 & 127 & 48.5 & 134 & 51.1 & 0 & 0 & 262 & 100 \\
\hline
\end{tabular}

Note: The WHO Western Pacific (1999) classification of AEFI:11,12

I.Programmatic errors, II. Injection reaction, III. Vaccine reaction, IV. Coincidental, V. Unknown.

$\%=$ Percentages of adverse events reported. 
TABle 4. Systemic and Local ReActions following DPWT/HB BASED ON AGE AND SEX

\begin{tabular}{|c|c|c|c|c|}
\hline & $\begin{array}{l}\text { First } \\
\text { dose } \\
\text { n (\%) }\end{array}$ & $\begin{array}{c}\text { Second } \\
\text { dose } \\
\text { n (\%) }\end{array}$ & $\begin{array}{l}\text { Third } \\
\text { dose } \\
\text { n (\%) }\end{array}$ & $\begin{array}{l}\text { Total } \\
\text { n (\%) }\end{array}$ \\
\hline \multicolumn{5}{|c|}{ Systemic reactions } \\
\hline \multicolumn{5}{|c|}{ Sex } \\
\hline Male & $25(53)$ & 21 & 21 (52) & $67(53)$ \\
\hline Female & $22(47)$ & 18 & $19(48)$ & $59(47)$ \\
\hline Total & 47 & 39 & 40 & $126(100)$ \\
\hline \multicolumn{5}{|c|}{ Age (months) } \\
\hline 2 & $33(70)$ & 0 & $0(0)$ & $33(26.2)$ \\
\hline 3 & $10(21)$ & 23 & $0(0)$ & $33(26.2)$ \\
\hline 4 & $2(4)$ & 11 & $29(73)$ & 42 (33.3) \\
\hline 5 & $2(4)$ & 4 & $8(20)$ & $14(11.1)$ \\
\hline 6 & $0(0)$ & 1 & $2(5)$ & $3(2.4)$ \\
\hline 7 & $0(0)$ & 0 & $1(3)$ & $1(0.8)$ \\
\hline Total & 47 & 39 & 40 & $126(100)$ \\
\hline \multicolumn{5}{|c|}{$\begin{array}{l}\text { Local reactions } \\
\text { Gender }\end{array}$} \\
\hline Male & 6 & 3 & 3 & 12 \\
\hline Female & 5 & 1 & 2 & 8 \\
\hline Total & 11 & 4 & 5 & 20 \\
\hline \multicolumn{5}{|c|}{ Age (months) } \\
\hline 2 & 5 & 0 & 0 & 5 \\
\hline 3 & 3 & 2 & 0 & 5 \\
\hline 4 & 1 & 1 & 2 & 4 \\
\hline 5 & 2 & 1 & 2 & 5 \\
\hline 6 & 0 & 0 & 1 & 1 \\
\hline 7 & 0 & 0 & 0 & 0 \\
\hline Total & 11 & 4 & 5 & 20 \\
\hline
\end{tabular}

adverse events in this study included 126 systemic $(60.3 \%)$ and 20 local reactions (9.5\%). A former study in Thailand found systemic and local reactions in $64 \%$ and $9 \%$ of total doses, respectively. ${ }^{4}$ A study in Spain reported systemic reaction in $73.9 \%$ and local reaction in $59.2 \% .^{5}$

According to the audit results of AEFI Committee Ministry of Health, most adverse events reported in this study were coincidental $(51.1 \%)$. These audit results confirmed the AEFI reports from Vaccine Safety Committee, Institute of Medicine (IOM). ${ }^{11-14}$

Most systemic reactions were found in 4-monthold infants (33.3\%). Local reactions were mostly reported in 2-, 3-, and 5-month-old infants. These adverse events were spread almost evenly between sexes. There was no previous report about the proportion of local and systemic reactions based on age and sex.

Mild fever was the most common systemic reaction reported in this study (45\%), followed by irritability (32\%) and high fever (16\%). The study in Lithuania showed that irritability occurred in $61 \%$ of doses, mild fever in $25.9 \%$ of doses, and high fever in $0.87 \%$ of doses. ${ }^{6}$ The Greece study reported mild fever (41.9\%), irritability (39.5\%), and high fever (3.2\%). ${ }^{7}$ Vomiting was reported following 9.5\% of doses in this study. A study in Bogor showed that vomiting occurred in $7.69-12.82 \%$ of doses. ${ }^{15}$ In this study, malaise, diarrhea, and wheals were reported following $5.7 \%, 4.2 \%$, and $2.8 \%$ of doses, respectively, and classified as coincidental events according to the audit results of AEFI Committee, Ministry of Health. There is no report about these events in previous studies.

Febrile convulsion was reported following 2 doses $(0.9 \%)$ of the vaccine in this study. No sequelae was found following these reactions. The Advisory Committee on Immunization Practices (ACIP) reported that convulsion with or without fever occurred following $0.05 \%$ doses of DPT vaccine, less than that reported in this study. ${ }^{16}$ However, it is stated in the literature that approximately $2-5 \%$ children younger than 5 years old have experienced febrile convulsion, greater than that found in this study. ${ }^{17}$ In this study, pale was reported in 1 doses $(0.5 \%)$ and classified as an injection reaction according to the audit results of AEFI Committee Ministry of Health. There is no report about convulsion and pale following immunization of DPwT/ HB from previous studies.

Local swelling was the most common local reaction reported in this study (9\%), followed by local pain $(0.5 \%)$. The study in Lithuania showed that local pain occurred in $52.9 \%$ of doses, and local swelling was found following $38.7 \%$ of doses. ${ }^{6}$ The study in Greece reported local pain (21.8\%) and swelling $(17.7 \%){ }^{7}$ Another study in Bogor found that local pain occurred in $42.05-46.67 \%$ of doses, and local swelling occurred in $14.87-22.05 \%$ of doses. ${ }^{15}$

Adverse events mostly occurred in 4-5 hours following immunization and lasted for 2-3 hours. The study in Bogor reported that most adverse events occurred in the first day and lasted less than 3 days. In this study, mild fever was mostly reported in 4-5 hours following immunization and resolved within 2 3 hours. The study in Bogor showed that mild fever mostly occurred in the first day, and resolved within 1.28-1.31 days. ${ }^{15}$ Most high fever in this study occurred in more than 72 hours and resolved within 2-3 hours, while Sundoro ${ }^{15}$ noted that high fever 
Diana M Jong et al: Adverse events of diphtheria, pertussis, tetanus, and hepatitis B vaccination

occurred in the first day, and lasted for 1.2-1.7 days. ${ }^{15}$ Irritability was mostly reported in 2-3 hours following immunization and resolved within 2-3 hours. Sundoro reported that irritability mostly occurred in the first day, and lasted for 1.6-1.8 days. ${ }^{15}$ Two cases of febrile convulsions occurred in 11.5 and 16 hours following immunization and each ceased in 1-5 minutes. There is no report about this event in other studies.

Most vomiting, diarrhea, malaise, and wheals occurred in more than 72 hours following immunization, and lasted less than 24 hours. A case of local pain was reported in 2-3 hours following immunization and resolved spontaneously within 24 hours. The Bogor study showed that vomiting and local pain were frequently reported in the first day and disappeared spontaneously in 1-2 days. ${ }^{15}$ Local swelling was frequently reported in 2-3 hours and disappeared spontaneously in 14-15 hours. Study in Bogor found that local swelling mostly occurred in the first day, and lasted for 1.53-1.97 days. ${ }^{15}$ No event was followed by sequelae and needed any hospitalization. The difference results in systemic and local reactions among these studies may be due to the subjectivity of the observers (parents) in reporting AEFI, and the different observation time among these studies.

We concluded that most AEFI in this study were coincidental, occurred and lasted less than 24 hours. No complication and hospitalization were reported following the AEFI. However, there were some limitations of this study, such as subjectivity of the observers (parents) in reporting AEFI, incapability to cover rare AEFI, and non-controlled study. A randomized controlled study of combined versus non-combined vaccines, with large samples and strict AEFI reporting observation, would be necessary in the future.

\section{References}

1. Kurstak E. Hepatitis B virus and disease. In: Kurstak C, Hossain A, Tuwaijiri A, editors. Viral hepatitis. Current status and issues. New York: Springer-Verlag; 1993. p. 59-137.

2. World Health Organization. Global perspectives on hepatitis. Newsletter of the International Task Force on Hepatitis B Immunization and the Program for Appropriate Technology in Health (PATH) 1993;4:1-8.
3. Decker MD, Edwards KM. Combination vaccines. In: Plotkin SA, Orenstein WA, editors. Vaccines. $3^{\text {rd }}$ ed. Philadelphia: Saunders; 1999. p. 508-30.

4. Poovorawan Y, Theamboonlers A, Sanpavat S, Pongpunlert W, Chumdermpadetsuk S, Safary A, et al. Comparison study of combined DTPw-HB vaccines and separate administration of DTPw and $\mathrm{HB}$ vaccines in Thai children. Asian Pac J Allergy Immunol 1999;17:113-20.

5. Aristegui J, Garrote E, Gonzalez A, Arrate JP, Perez A, Vandepapeliere P. Immune response to a combined hepatitis $\mathrm{B}$, diphtheria, tetanus, and whole-cell pertussis vaccine administered to infants at 2,4 , and 6 months of age. Vaccine 1997;15:7-9.

6. Usonis V, Bakasenas V, Taylor D, Vandepapeliere P. Immunogenicity and reactogenicity of a combined DTPw-hepatitis B vaccine in Lithuanian infants. Eur J Pediatr 1996;155:189-93.

7. Papaevangelou G, Karvelis E, Alexiou D, Kiossoglou K, Roumeliotou A, Safary A, et al. Evaluation of a combined tetravalent diphtheria, tetanus, whole-cell pertussis and hepatitis $B$ candidate vaccine administered to healthy infants according to a threedose vaccination schedule. Vaccine 1995;13:175-8.

8. Poovorawan Y. Experience of combined tetravalent diphtheria, tetanus, whole-cell pertussis and hepatitis B vaccine in Thailand. Southeast Asian J Trop Med Public Health 1997;28:496-9.

9. Hadinegoro SRS. Vaksin kombinasi. In: Ranuh IGN, Soeyitno H, Hadinegoro SRS, Kartasasmita C, editors. Buku imunisasi di Indonesia. $1^{\text {st }}$ ed. Jakarta: Ikatan Dokter Anak Indonesia; 2001. p. 147-56.

10. Pichichero ME. New combination vaccines. Pediatr Clin North Am 2000;47:407-26.

11. World Health Organization. Immunization Safety Surveillance. Geneva: WHO; 1999.

12. Komite Nasional Pengkajian \& Penanggulangan Kejadian Ikutan Pasca Imunisasi. Pedoman tatalaksana medik kejadian ikutan pasca imunisasi bagi petugas kesehatan. $4^{\text {th }}$ ed. Jakarta: KN PP KIPI; 2002.

13. Akib AAP. Kejadian ikutan pasca-imunisasi. In: Trihono PP, Pudjiarto PS, Syarif DR, Hegar B, Gunardi H, Oswari H, $\mathrm{dkk}$, editors. Hot topics in pediatrics II. Proceedings of the $45^{\text {th }}$ Pediatrics Continuing Medical Education, Medical School, University of Indonesia; 2002 Feb 18-19; Jakarta, Indonesia. Jakarta: Balai Penerbit FKUI; 2002. p. 302-11.

14. Chen RT. Safety of vaccines. In: Plotkin SA, Orenstein WA, editors. Vaccines. $3^{\text {rd }}$ ed. Philadelphia: Saunders; 1999. p. 1144-63. 


\section{Paediatrica Indonesiana}

15. Sundoro J. Respons antibodi dan kejadian ikutan pascaimunisasi pada bayi sehat yang diimunisasi DPT/ $\mathrm{HB}$ kombinasi dibandingkan dengan DPT $+\mathrm{HB}$ terpisah di Kabupaten Bogor, Jawa Barat, tahun 2001-2002 [dissertation]. Jakarta: University of Indonesia; 2003.

16. Advisory Committee on Immunization Practices. Update: vaccine side effects, adverse reactions, contraindications, and precautions. Recommendation of the Advisory Committee on Immunization Practices (ACIP). MMWR 1996;45:1-33.

17. Soetomenggolo TS. Kejang demam. In: Soetomenggolo TS, Ismael S, editors. Buku ajar neurologi anak. $1^{\text {st }}$ ed. Jakarta: Ikatan Dokter Anak Indonesia; 1999. p. 244-52. 